\title{
INTERACTION BETWEEN CONSUMERS AND EMERGING FORMS OF ARTIFICIAL INTELLIGENCE: A DISCRIMINANT ANALYSIS
}

\author{
Corina Pelău* \\ Bucharest University of Economic Studies, Romania \\ E-mail: corina.pelau@fabiz.ase.ro \\ Irina Ene \\ Bucharest University of Economic Studies, Romania \\ E-mail: irina3ene@yahoo.com
}

(Received: March 2020; Accepted: May 2020; Published: June 2020)

\begin{abstract}
The interaction between consumers and companies has been changed because of the development and implementation of artificial intelligence. On one hand, the implementation of artificial intelligence systems increases the efficiency and rapidity of certain processes, by making the life of consumers and companies easier. On the other hand, their implementation brings certain challenges because of the changes it involves, including the acceptance of artificial intelligence systems by the consumers, the ability to learn how to operate the robots as well as the protection of the information gathered by these systems. In this paper, we aim to measure the acceptance of consumers regarding different forms of artificial intelligence systems. By applying a discriminant analysis, we measure the preference of consumers towards human versus robot interaction as well as between different types of robots with different forms and degrees of anthropomorphic characteristics. The results show that consumers prefer human interaction to the interaction with robots, especially in cases where they are not familiar with the robot interaction. Besides, they prefer the communication to classic robots in comparison to human holograms and they have a certain curiosity towards humanoid robots in opposition to classic robots.
\end{abstract}

Keywords: robots, consumer perception, artificial intelligence, innovation

JEL Codes: M10, M31

*Corresponding author: Corina Pelău. E-mail: corina.pelau@fabiz.ase.ro

Copyright $(0) 2020$ The Author(s). Published by VGWU Press

This is an Open Access article distributed under the terms of the Creative Commons BY 4.0 license (Creative Commons - Attribution 4.0 International - CC BY 4.0) which permits unrestricted use, distribution, and reproduction in any medium, provided the original author and source are credited.

$S$ sciendo Studia Universitatis "Vasile Goldis" Arad. Economics Series Vol 30 Special Issue 2/2020 ISSN: 1584-2339; (online) ISSN: $2285-3065$ 
Pelău, C., Ene, I., (2020)

Interaction between consumers and emerging forms of artificial intelligence: a discriminant analysis

\section{Introduction}

The general idea of artificial intelligence systems that can replicate personal experience and personality traits is not yet a realistic image. It is highly unlikely at this point to find an artificial intelligence system that can outperform human capacities that drive superior intuitive decision making or which can learn or imitate intuition, as this is clearly a non-transferable human attribute (Buchanan \& O'Connell, 2006). However, according to a study, artificial intelligence was ranked as one of the Essential Eight technologies, which will completely transform all industries by $72 \%$ of business leaders (PwC $20^{\text {th }}$ Global CEO Survey, 2017). This is only possible as long as customers are happy to embrace such changes. While artificial intelligence systems can handle a decision-making approach, they are still unable to understand common-sense situations. This means, that in comparison to the human workforce, AI is less viable in unpredictable situations (Guszcza et al., 2017; Brynjolfsson \& McAfee, 2012). There are examples of elements which can extend the cognitive utilities of artificial intelligence and can augment the humanlike abilities. These include natural language processing, which implies that machines can analyze and understand the human language, or machine learning and vision, which implies algorithms that enable systems processes as learning or image inspection and analysis.

Artificial intelligence systems can easily be mistaken for technology-enabled services by the inexperienced eye. Therefore, it is important to clear up the differences between the two of them. Artificial Intelligence is an umbrella term for smart technologies that are able to learn from their environments. The AI is incorporated in robotic process automation software (RPA) which helps users to achieve process optimization. Moreover, artificial intelligence is also incorporated into machine learning, which allows systems to learn from past data and remember patterns in order to predict future outcomes (PwC Technology Series, 2017). Typical examples of AI-based applications are Siri, Alexa, or Cortana. While Artificial intelligence enables devices to adapt to their environments and perform tasks that would normally require human intervention like answering questions, suggesting solutions, diagnosing problems, or taking actions, technology-enabled services are automations, which are able to perform simple tasks and are based on predefined rules and algorithms. Compared to artificial intelligence, the technology-enabled services do not learn from their past data but require customer learning in exchange (Lee \& Cranage, 2018). Examples of technology-enabled services are the mobile self-check-ins from airports or self-service kiosks (Liu \& Mattila, 2019). 
Pelău, C., Ene, I., (2020)

Interaction between consumers and emerging forms of artificial intelligence: a discriminant analysis

\section{Literature review}

Artificial intelligence is constantly changing the relationship between machines and humans by offering more ways of including it in our daily routines. There are different forms of artificial intelligence suitable for each of our needs. For example, the systems based on assisted intelligence like industrial robots are helping us to perform tasks better or faster, while systems based on augmented intelligence are enabling humans to make better choices, for example by suggesting shopping items based on the customer's past behavior. Furthermore, autonomous intelligence systems enable decision-making processes without the need for human involvement, for example in the case of fully automated self-driving cars. However, a study conducted by PwC shows that $76 \%$ of CEOs are concerned about the possibility of system collapse which can affect the AI algorithms and decisionmaking models (PWC Global CEO Pulse Survey, 2017)

Not only the company leaders worry about the risks involved in the quick expansion of AI-based applications. The consumer's tolerance towards artificial intelligence being implemented in the service sector and towards the overall changes is also a topic that is being addressed in the research environment. On one hand, technology contributes to making processes more efficient, which often includes or leads to cutting personnel costs (Brynjolfsson \& McAfee, 2014). Due to the increased abilities of artificial intelligence systems, more and more humans are being displaced, while job roles are being rethought. Especially in the service sector, the consumer's interaction with robots instead of actual employees often leads to challenges on the emotional and psychological level, as the traditional services are being transformed. Some fear that artificial intelligence systems will somehow outperform human abilities and will become a danger to humankind (Barrat, 2015). On the other hand, robots lack a certain gut feeling, which can be defined as the ability to understand a context and make a decision without relying on a certain logic or rational thinking (Sadler-Smith \& Shefy, 2004), which implies that the intelligence of a machine can not increase without humans helping it by adding new patterns which have specific algorithms set up in the background (Taylor et al., 2014)

The challenge of decreasing the anxiety towards AI and making such devices look friendlier to the consumers often results in the implementation of human-like artificial intelligence systems. This brings along risks to the company, as there are plenty of studies that show that anthropomorphism does not increase the consumer's tolerance towards robots (Goudey \& Bonnin, 2016; Pelau \& Ene, 2018). However, such attempts may fail and the substitution of the human workforce with robots can lead to situations in which the robots can function improperly, which result in customer embarrassments (Liu \& Mattila, 2019). Artificial intelligence and humans should not be substitutes but complements. 
Pelău, C., Ene, I., (2020)

Interaction between consumers and emerging forms of artificial intelligence: a discriminant analysis

Therefore, artificial intelligence should only have the role of augmenting and not replacing human inputs, as it is meant to become an integrated part within us while fitting our needs, the same way humankind manipulated cattle and pets to fit our needs (Thrall et al., 2010). Therefore, we need to recognize also the amazing potential AI has to improve our lives, our health, our happiness, while also generating a large number of new job roles (Metzinger et. al, 2018).

\section{Methodology and empirical data}

The objective of this research is to determine the preference of the consumers towards the interaction with human consultants, classic robots, or humanoids robots for fulfilling different chores. The purpose is to determine if the consumer prefers artificial intelligence systems over human consultants and if the anthropomorphized characteristics of robots determine consumers to choose them over classic looking robots. Previous research has proven that consumers still prefer classic looking robots over humanoid robots (Pelau \& Ene, 2018). The aim of the paper is to determine which conditions and demographic characteristics of consumers influence the acceptance of classic looking robots over the ones with human-like looks. For this analysis, a survey has been carried out on a sample of 252 respondents.

Five cases have been presented to each of the respondents. Firstly, they had to evaluate on a Likert scale from 1 to 7 (where 7 represents totally agree and 1 represents totally disagree) if they would choose a certain service (named throughout the analysis as case a). Secondly, they had to evaluate in the form of a constant-sum answer their tendency (expressed in percentages) of choosing each of the two situations, while the sum of the percentages had to equal $100 \%$. This second part was named throughout the analysis as case b. In the first two case studies, the respondents had to choose between a classic looking like a computer system and a human consultant for online banking and legal advice. Nowadays, consumers are more accustomed to online banking systems in comparison to remotely asking legal advice through a computer. In the third case study, the consumers had to choose between the humanoid robot Sophia and a human adviser for helping them with cooking advice. In the fourth case, they had to choose between a human hologram and a classic looking robot while asking for directions in an airport. In the fifth case, the respondents had to choose between having a job interview either with a classic looking robot or with a humanoid looking robot. The five research situations are presented in table 1.

\footnotetext{
4 Studia Universitatis "Vasile Goldis" Arad. Economics Series Vol 30 Special Issue 2/2020 $\checkmark$ sciendo ISSN: 1584-2339; (online) ISSN: $2285-3065$

Web: publicatii.uvvg.ro/index.php/studiaeconomia. Pages $1-12$
} 
Pelău, C., Ene, I., (2020)

Interaction between consumers and emerging forms of artificial intelligence: a discriminant analysis

\begin{tabular}{lll}
\hline & \multicolumn{1}{c}{$\begin{array}{c}\text { Table 1 Research situations for the interaction between consumers and } \\
\text { humans, robots and humanoid robots }\end{array}$} \\
\hline & $\begin{array}{l}\text { Interaction between consumer } \\
\text { and .... }\end{array}$ & $\begin{array}{l}\text { Interaction between consumer } \\
\text { and ... }\end{array}$ \\
\hline Case 105 & $\ldots$ classic online banking & $\ldots$ human consultant in banking \\
\hline Case 106 & $\ldots$ legal online advice & .. human legal consultant \\
\hline Case 108 & $\begin{array}{l}\text {... humanoid robot as a cooking } \\
\text { adviser }\end{array}$ & $\begin{array}{l}\text {.. human consultant as cooking } \\
\text { adviser }\end{array}$ \\
\hline Case 109 & $\begin{array}{l}\text {.. human hologram for direction } \\
\text { search }\end{array}$ & ... classic robot for direction search \\
\hline Case 107 & $\ldots$ classic robot for job interview & ... humanoid robot for job interview \\
\hline
\end{tabular}

While in the first two cases the respondents had to choose between a computer system and a human consultant, the last three cases were manipulated in such a manner, in order to introduce different forms of anthropomorphized robots. The third case was meant to ask the consumers to choose between receiving information from a humanoid looking robot or from a human being, while in the first two cases they had to choose between receiving advice from a classic looking robot and a human being. In the fourth and fifth cases, the respondents had to choose between receiving information from two types of robots, as the human being is not a choice anymore. The fourth case compared the preference towards a classic looking robot versus a human hologram, while the fifth case compared a classic looking robot versus a humanoid robot.

The results of the survey have been concluded based on a discriminant analysis in SPSS 20, with the purpose of determining significant differences between the two situations presented in each of the five cases. The significant differences between respondent's choices have been tested depending on two demographic characteristics of the consumer: gender (female and male consumers) and age (people younger than 40 years and people older than 40 years. The sample included 161 people younger than 40 years, 91 people older than 40 years, 132 females and 120 male respondents.

\section{Empirical results}

The first two cases focus on the consumers' preference towards a human consultant or a classic computer system. The results show that in the case of online banking, which is a rather familiar system for the consumers, there are only average significances for the preference for one option or another as it can be observed in table 2. The results for the total sample show that there is an increased preference for the online computer system for both the Likert scale question $\left(\mathrm{M}_{1 \mathrm{a}}=4.48\right.$, $\mathrm{F}=5.904, \mathrm{p}=0.015<0.5)$ and the constant sum question $\left(\mathrm{M}_{1 \mathrm{~b}}=52.71, \mathrm{~F}=5.160\right.$, 
Pelău, C., Ene, I., (2020)

Interaction between consumers and emerging forms of artificial intelligence: a discriminant analysis

$\mathrm{p}=0.024<0.5)$ in comparison to the human interaction $\left(\mathrm{M}_{1 \mathrm{a}}=4.01 ; \mathrm{M}_{1 \mathrm{~b}}=46.50\right)$.

However, this preference shows a difference for consumers depending on their age.

Table 2 Discriminant analysis results regarding the consumers' preference for online banking or classic banking (human interaction)

\begin{tabular}{|c|c|c|c|c|c|c|}
\hline Variable & $\begin{array}{c}\text { Mean in } \\
\text { computer } \\
\text { interaction }\end{array}$ & $\begin{array}{c}\text { Mean in } \\
\text { human } \\
\text { interaction }\end{array}$ & $\begin{array}{l}\text { Standard } \\
\text { deviation } \\
\text { computer } \\
\text { interaction }\end{array}$ & $\begin{array}{c}\text { Standard } \\
\text { deviation } \\
\text { human } \\
\text { interaction }\end{array}$ & $\begin{array}{c}\text { F value } \\
\text { (df:1,502) }\end{array}$ & $\mathbf{P}$ \\
\hline Q105a & 4.48 & 4.01 & 2.18 & 2.14 & 5.90 & 0.015 \\
\hline Q105b & 52.71 & 46.50 & 30.77 & 30.60 & 5.16 & 0.024 \\
\hline Q105a Feminine & 4.59 & 4.00 & 2.15 & 2.16 & 4.94 & 0.027 \\
\hline Q105b Feminine & 53.12 & 45.03 & 30.28 & 30.22 & 4.72 & 0.031 \\
\hline Q105a Masculine & 4.36 & 4.03 & 2.21 & 2.12 & 1.41 & 0.236 \\
\hline Q105b Masculine & 52.26 & 48.13 & 31.42 & 31.06 & 1.05 & 0.307 \\
\hline Q105a Age $<40$ & 5.09 & 3.53 & 1.91 & 1.99 & 51.70 & 0.000 \\
\hline Q105b Age $<40$ & 61.89 & 38.09 & 26.22 & 25.86 & 67.20 & 0.000 \\
\hline Q105a Age>40 & 3.39 & 4.86 & 2.22 & 2.14 & 20.742 & 0.000 \\
\hline Q105b Age >40 & 36.48 & 61.39 & 31.64 & 32.72 & 27.248 & 0.000 \\
\hline
\end{tabular}

Source: author's own research

Consumers younger than 40 years prefer in a significant way to solve their issues using online banking $\left(\mathrm{M}_{1 \mathrm{a}}=5.09, \mathrm{~F}=51.709, \mathrm{p}=0.000\right.$ and $\mathrm{M}_{1 \mathrm{~b}}=61.89, \mathrm{~F}=67.200$, $\mathrm{p}=0.000)$ in comparison to the human interaction $\left(\mathrm{M}_{1 \mathrm{a}}=3.53 ; \mathrm{M}_{1 b}=38.09\right)$. In opposition to this, people older than 40 years prefer to solve their issues with human interaction, while actually going to the bank $\left(\mathrm{M}_{1 \mathrm{a}}=4.86, \mathrm{~F}=20.742, \mathrm{p}=0.000\right.$; $\mathrm{M}_{1 \mathrm{~b}}=61.39, \mathrm{~F}=27.248, \mathrm{p}=0.000$ ). The standard deviation for the people older than 40 years is higher than those for young people, showing a wider range of preferences. The analysis for men and women show that no significant differences are depending on gender. Moreover the male respondents have no significant preferences between the two choices $\left(\mathrm{F}_{1 \mathrm{a}}=1.41, \mathrm{p}=0.236>010\right.$ and $\mathrm{F}_{1 \mathrm{~b}}=1.05$, $\mathrm{p}=0.307>0.10$ ).

In the case of receiving legal advice, the preference of the consumer is oriented towards the human consultant $\left(\mathrm{M}_{2 \mathrm{a}}=5.68, \mathrm{~F}=408.48, \mathrm{p}=0.000\right.$ and $\mathrm{M}_{2 \mathrm{~b}}=73.18$, $\mathrm{F}=501.51, \mathrm{p}=0.000)$ in the detriment of the computer system $\left(\mathrm{M}_{2 \mathrm{a}}=2.74\right.$ and $\mathrm{M}_{2 \mathrm{~b}}=26.94$ ). This preference is significant for both gender and both age groups, having similar values for women $\left(\mathrm{M}_{2 \mathrm{a}}=5.78, \mathrm{~F}=247.76, \mathrm{p}=0.000\right.$ and $\mathrm{M}_{2 \mathrm{~b}}=73.47$,

\footnotetext{
6 Studia Universitatis "Vasile Goldis" Arad. Economics Series Vol 30 Special Issue 2/2020 $\checkmark$ sciendo ISSN: 1584-2339; (online) ISSN: $2285-3065$

Web: publicatii.uvvg.ro/index.php/studiaeconomia. Pages $1-12$
} 
Pelău, C., Ene, I., (2020)

Interaction between consumers and emerging forms of artificial intelligence: a discriminant analysis

$\mathrm{F}=305.97, \mathrm{p}=0.000)$, men $\left(\mathrm{M}_{2 \mathrm{a}}=5.57, \mathrm{~F}=165.58, \mathrm{p}=0.000\right.$ and $\mathrm{M}_{2 \mathrm{~b}}=72.85$, $\mathrm{F}=202.96, \mathrm{p}=0.000)$, people younger than 40 years $\left(\mathrm{M}_{2 \mathrm{a}}=5.57, \mathrm{~F}=210.313, \mathrm{p}=0.000\right.$ and $\left.\mathrm{M}_{2 \mathrm{~b}}=70.95, \mathrm{~F}=255.684, \mathrm{p}=0.000\right)$ and people older than 40 years $\left(\mathrm{M}_{2 \mathrm{a}}=5.87\right.$, $\mathrm{F}=214.000, \mathrm{p}=0.000$ and $\mathrm{M}_{2 \mathrm{~b}}=77.12, \mathrm{~F}=268.585, \mathrm{p}=0.000$ ). All results for this case can be observed in table 3 .

Table 3 Discriminant analysis results regarding the consumers' preference for a classic computer system or human adviser for legal advice

\begin{tabular}{|c|c|c|c|c|c|c|}
\hline Variable & $\begin{array}{c}\text { Mean in } \\
\text { computer } \\
\text { interaction }\end{array}$ & $\begin{array}{c}\text { Mean in } \\
\text { human } \\
\text { interaction }\end{array}$ & $\begin{array}{l}\text { Standard } \\
\text { deviation } \\
\text { computer } \\
\text { interaction }\end{array}$ & $\begin{array}{c}\text { Standard } \\
\text { deviation } \\
\text { human } \\
\text { interaction }\end{array}$ & $\begin{array}{c}\text { F value } \\
(\mathrm{df}: 1, \mathbf{5 0 2})\end{array}$ & $\mathbf{P}$ \\
\hline Q106a & 2.74 & 5.68 & 1.69 & 1.57 & 408.48 & 0.000 \\
\hline Q106b & 26.94 & 73.18 & 23.28 & 23.06 & 501.51 & 0.000 \\
\hline Q106a Feminine & 2.74 & 5.78 & 1.61 & 1.52 & 247.76 & 0.000 \\
\hline Q106b Feminine & 26.25 & 73.47 & 21.61 & 22.24 & 305.97 & 0.000 \\
\hline Q106a Masculine & 2.74 & 5.57 & 1.77 & 1.62 & 165.58 & 0.000 \\
\hline Q106b Masculine & 27.70 & 72.85 & 25.05 & 24.03 & 202.96 & 0.000 \\
\hline Q106a Age $<40$ & 2.88 & 5.57 & 1.69 & 1.63 & 210.313 & 0.000 \\
\hline Q106b Age $<40$ & 29.15 & 70.95 & 23.70 & 23.20 & 255.684 & 0.000 \\
\hline Q106a Age>40 & 2.49 & 5.87 & 1.66 & 1.45 & 214.000 & 0.000 \\
\hline Q106b Age>40 & 23.04 & 77.12 & 22.11 & 22.40 & 268.585 & 0.000 \\
\hline
\end{tabular}

This result shows that the preference of the consumer towards advice from a computer/ intelligent system or human consultancy depends very much on the field or domain of the interaction. The systems to which the consumer is acquainted are easier to be accepted. The online banking systems are also more consumer-friendly in comparison to remote legal advice services, which makes them also more preferred by the user.

In the third case regarding the cooking receipt recommendation or tutorial, the choice of the consumer is in a significant way directed towards the human interaction, as it can be observed in table 4 . Most of the consumers prefer the human cook $\left(\mathrm{M}_{3 \mathrm{a}}=5.73, \mathrm{~F}=411.08, \mathrm{p}=0.000\right.$ and $\left.\mathrm{M}_{3 \mathrm{~b}}=71.91, \mathrm{~F}=533.07, \mathrm{p}=0.000\right)$ in detriment of a humanoid robot in the role of a cook $\left(\mathrm{M}_{3 \mathrm{a}}=2.79\right.$ and $\left.\mathrm{M}_{3 \mathrm{~b}}=27.33\right)$. There are significant values for all demographic groups, including women $\left(\mathrm{M}_{3 \mathrm{a}}=5.83, \mathrm{~F}=257.68, \mathrm{p}=0.000\right.$ and $\left.\mathrm{M}_{3 \mathrm{~b}}=71.71, \mathrm{~F}=290.46, \mathrm{p}=0.000\right)$, men 
Pelău, C., Ene, I., (2020)

Interaction between consumers and emerging forms of artificial intelligence: a discriminant analysis

$\left(\mathrm{M}_{3 \mathrm{a}}=5.63, \mathrm{~F}=161.67, \mathrm{p}=0.000\right.$ and $\left.\mathrm{M}_{3 \mathrm{~b}}=72.14, \mathrm{~F}=241.43, \mathrm{p}=0.000\right)$, people younger than 40 years $\left(\mathrm{M}_{3 \mathrm{a}}=5.59, \mathrm{~F}=188.993, \mathrm{p}=0.000\right.$ and $\mathrm{M}_{3 \mathrm{~b}}=69.62, \mathrm{~F}=274.824$, $\mathrm{p}=0.000)$ and people older than 40 years $\left(\mathrm{M}_{3 \mathrm{a}}=5.98, \mathrm{~F}=268.085, \mathrm{p}=0.000\right.$ and $\left.\mathrm{M}_{3 \mathrm{~b}}=75.97, \mathrm{~F}=281.247, \mathrm{p}=0.000\right)$.

Table 4 Discriminant analysis results regarding the consumers' preference towards a humanoid robot or towards a human being for cooking advice

\begin{tabular}{|c|c|c|c|c|c|c|}
\hline Variable & $\begin{array}{c}\text { Mean in } \\
\text { humanoid } \\
\text { robot } \\
\text { interaction }\end{array}$ & $\begin{array}{c}\text { Mean in } \\
\text { human } \\
\text { interaction }\end{array}$ & $\begin{array}{c}\text { Standard } \\
\text { deviation } \\
\text { humanoid } \\
\text { robot } \\
\text { interaction }\end{array}$ & $\begin{array}{c}\text { Standard } \\
\text { deviation } \\
\text { human } \\
\text { interaction }\end{array}$ & $\begin{array}{c}\text { F value } \\
(\mathrm{df}: 1, \mathbf{5 0 2})\end{array}$ & $\mathbf{P}$ \\
\hline Q108a & 2.79 & 5.73 & 1.69 & 1.55 & 411.08 & 0.000 \\
\hline Q108b & 27.33 & 71.91 & 21.24 & 22.09 & 533.07 & 0.000 \\
\hline Q108a Feminine & 2.78 & 5.83 & 1.63 & 1.43 & 257.68 & 0.000 \\
\hline Q108b Feminine & 26.85 & 71.71 & 20.53 & 22.19 & 290.46 & 0.000 \\
\hline Q108a Masculine & 2.80 & 5.63 & 1.77 & 1.68 & 161.67 & 0.000 \\
\hline Q108b Masculine & 27.85 & 72.14 & 22.07 & 22.07 & 241.43 & 0.000 \\
\hline Q108a Age $<40$ & 3.00 & 5.59 & 1.74 & 1.64 & 188.993 & 0.000 \\
\hline Q108b Age $<40$ & 30.37 & 69.62 & 21.23 & 21.23 & 274.824 & 0.000 \\
\hline Q108a Age $>40$ & 2.42 & 5.98 & 1.55 & 1.37 & 268.085 & 0.000 \\
\hline Q108b Age $>40$ & 21.94 & 75.97 & 20.27 & 23.09 & 281.247 & 0.000 \\
\hline
\end{tabular}

In the fourth case, the respondents had to choose between a human hologram and classic looking robot. The highest mean values in favor of the human cook can be observed for people older than 40 years, while the humanoid robot receives the highest acceptance from the people younger than 40 years. It must be also mentioned that the case 2 which studies the choice between a computer system and a human being for legal advice and case 3, which studies the choice between a humanoid robot and a human being for cooking advice, have the highest F-values showing, therefore, the highest differences between the two choices and an obvious inclination towards one of them. The gender analysis shows that both women $\left(\mathrm{M}_{4 \mathrm{a}}=4.87, \mathrm{~F}=18.87, \mathrm{p}=0.000\right.$ and $\left.\mathrm{M}_{4 \mathrm{~b}}=57.49, \mathrm{~F}=28.41, \mathrm{p}=0.000\right)$ and men $\left(\mathrm{M}_{4 \mathrm{a}}=4.85, \mathrm{~F}=20.86, \mathrm{p}=0.000\right.$ and $\left.\mathrm{M}_{4 \mathrm{~b}}=59.20, \mathrm{~F}=36.86, \mathrm{p}=0.000\right)$ prefer the classic robot over the human hologram. The analysis based on age groups shows a more significant result for the preference of the people younger than 40 years for the classic robot $\left(\mathrm{M}_{4 \mathrm{a}}=5.15, \mathrm{~F}=40.870, \mathrm{p}=0.000\right.$ and $\left.\mathrm{M}_{4 \mathrm{~b}}=59.06, \mathrm{~F}=59.319, \mathrm{p}=0.000\right)$, 
Pelău, C., Ene, I., (2020)

Interaction between consumers and emerging forms of artificial intelligence: a discriminant analysis

in comparison to the hologram. The preference is less obvious for people older than 40 years as $\mathrm{F}_{4 \mathrm{a}}=5.471(\mathrm{p}=0.020<0.05)$. Despite this, the average of the preferences is higher both in the case of the Likert scale and constant sum questions.

Table 5 Discriminant analysis results regarding the consumers' preference for interaction with a human hologram or with a classic robot

\begin{tabular}{|c|c|c|c|c|c|c|}
\hline Variable & $\begin{array}{c}\text { Mean in } \\
\text { human } \\
\text { hologram } \\
\text { interaction }\end{array}$ & $\begin{array}{c}\text { Mean in } \\
\text { robot } \\
\text { interaction }\end{array}$ & $\begin{array}{c}\text { Standard } \\
\text { deviation } \\
\text { human } \\
\text { hologram } \\
\text { interaction }\end{array}$ & $\begin{array}{c}\text { Standard } \\
\text { deviation } \\
\text { in robot } \\
\text { interaction }\end{array}$ & $\begin{array}{c}\text { F value } \\
\text { (df:1,502) }\end{array}$ & $\mathbf{P}$ \\
\hline Q109a & 3.79 & 4.86 & 1.88 & 1.92 & 39.77 & 0.000 \\
\hline Q109b & 41.65 & 58.30 & 23.17 & 23.16 & 65.08 & 0.000 \\
\hline Q109a Feminine & 3.85 & 4.87 & 1.89 & 1.93 & 18.87 & 0.000 \\
\hline Q109b Feminine & 42.43 & 57.49 & 22.95 & 22.93 & 28.41 & 0.000 \\
\hline Q109a Masculine & 3.73 & 4.85 & 1.88 & 1.92 & 20.86 & 0.000 \\
\hline Q109b Masculine & 40.79 & 59.20 & 23.48 & 23.48 & 36.86 & 0.000 \\
\hline Q109a Age $<40$ & 3.88 & 5.15 & 1.78 & 1.79 & 40.870 & 0.000 \\
\hline Q109b Age $<40$ & 40.87 & 59.06 & 21.20 & 21.18 & 59.319 & 0.000 \\
\hline Q109a Age $>40$ & 3.64 & 4.36 & 2.05 & 2.06 & 5.471 & 0.020 \\
\hline Q109b Age >40 & 43.03 & 56.96 & 26.38 & 26.38 & 12.689 & 0.000 \\
\hline
\end{tabular}

The fifth case points out the fact that consumers prefer humanoid robots $\left(\mathrm{M}_{5 \mathrm{a}}=4.49\right.$, $\mathrm{F}=71.92, \mathrm{p}=0.000$ and $\mathrm{M}_{5 \mathrm{~b}}=60.56, \mathrm{~F}=107.65, \mathrm{p}=0.000$ ) in the detriment of classic robots $\left(\mathrm{M}_{5 \mathrm{a}}=3.06\right.$ and $\left.\mathrm{M}_{5 \mathrm{~b}}=39.00\right)$ to take part in a job interview. This preference is expressed by all demographic groups. Women $\left(\mathrm{M}_{5 \mathrm{a}}=4.75, \mathrm{~F}=63.63, \mathrm{p}=0.000\right.$ and $\mathrm{M}_{5 \mathrm{~b}}=62.82, \mathrm{~F}=100.92, \mathrm{p}=0.000$ ) have higher values for the preference of humanoid robots, in comparison to men $\left(\mathrm{M}_{5 \mathrm{a}}=4.21, \mathrm{~F}=16.59, \mathrm{p}=0.000\right.$ and $\mathrm{M}_{5 \mathrm{~b}}=58.08$, $\mathrm{F}=24.91, \mathrm{p}=0.000)$. People younger than 40 years $\left(\mathrm{M}_{5 \mathrm{a}}=4.61, \mathrm{~F}=51.42, \mathrm{p}=0.000\right.$ and $\mathrm{M}_{5 \mathrm{~b}}=61.30, \mathrm{~F}=86.37, \mathrm{p}=0.000$ ) have also higher values for the preference of humanoid robots, in comparison to people older than 40 years $\left(\mathrm{M}_{5 \mathrm{a}}=4.28, \mathrm{~F}=21.52\right.$, $\mathrm{p}=0.000$ and $\left.\mathrm{M}_{5 \mathrm{~b}}=59.26, \mathrm{~F}=26.43, \mathrm{p}=0.000\right)$. At the same time, women $\left(\mathrm{M}_{5 \mathrm{a}}=2.94\right.$ and $\left.\mathrm{M}_{5 \mathrm{~b}}=36.34\right)$ and people older than 40 years $\left(\mathrm{M}_{5 \mathrm{a}}=2.91\right.$ and $\left.\mathrm{M}_{5 \mathrm{a}}=39.53\right)$ have lower ratings for the classic looking robot, proving that they will not like to interact with this kind of technology in this concrete case. 
Pelău, C., Ene, I., (2020)

Interaction between consumers and emerging forms of artificial intelligence: a discriminant analysis

Table 6 Discriminant analysis results regarding the consumers' preference for a classic looking robot or a humanoid robot

\begin{tabular}{|c|c|c|c|c|c|c|}
\hline Variable & $\begin{array}{l}\text { Mean } \\
\text { for } \\
\text { classic } \\
\text { robot } \\
\end{array}$ & $\begin{array}{l}\text { Mean for } \\
\text { humanoid } \\
\text { robot }\end{array}$ & $\begin{array}{c}\text { Standard } \\
\text { deviation } \\
\text { Classic } \\
\text { robot } \\
\end{array}$ & $\begin{array}{c}\text { Standard } \\
\text { deviation } \\
\text { humanoid } \\
\text { robot }\end{array}$ & $\begin{array}{c}\text { F value } \\
\text { (df:1,502) }\end{array}$ & $\mathbf{P}$ \\
\hline Q107a & 3.06 & 4.49 & 1.75 & 2.01 & 71.92 & 0.000 \\
\hline Q107b & 39.00 & 60.56 & 23.25 & 23.41 & 107.65 & 0.000 \\
\hline Q107a Feminine & 2.94 & 4.75 & 1.71 & 1.94 & 63.63 & 0.000 \\
\hline Q107b Feminine & 36.34 & 62.82 & 21.19 & 21.62 & 100.92 & 0.000 \\
\hline Q107a Masculine & 3.20 & 4.21 & 1.79 & 2.05 & 16.59 & 0.000 \\
\hline Q107b Masculine & 41.91 & 58.08 & 25.08 & 25.08 & 24.91 & 0.000 \\
\hline Q107a Age $<40$ & 3.15 & 4.61 & 1.68 & 1.95 & 51.42 & 0.000 \\
\hline Q107b Age $<40$ & 38.69 & 61.30 & 21.82 & 21.82 & 86.37 & 0.000 \\
\hline Q107a Age $>40$ & 2.91 & 4.28 & 1.88 & 2.10 & 21.52 & 0.000 \\
\hline Q107b Age $>40$ & 39.53 & 59.26 & 25.70 & 26.05 & 26.43 & 0.000 \\
\hline
\end{tabular}

\section{Conclusions}

This article presents initial research about the impact of artificial intelligence and anthropomorphized characteristics of robots on the consumers' preference and trust. According to the results of this research, consumers prefer nowadays the human interaction over the interaction with robots or artificial intelligence, especially in the domains in which they are not used to using a machine. Moreover, consumers prefer classic looking robots over human holograms and humanoid robots over classic looking ones. Despite these results, the people younger than 40 years have had higher evaluations for all situations involving robots or artificial intelligence. This proves that younger people are more open to interaction with robots and this will facilitate the development of artificial intelligence in the future. The results have also shown that the acceptance of anthropomorphized artificial intelligence systems depend very much on the situation, implementation method, and design of the humanoid characteristics. For instance, human holograms, which include technology with a human touch, are less preferred compared to classic looking robots for doing certain services, while humanoid robots are preferred over classic looking robots (eg. in case of a job interview). The lack of acceptance of human-like characteristics for artificial intelligence systems has also been proven before (Pelau \& Ene, 2018). The context in which the interaction takes place could 
Pelău, C., Ene, I., (2020)

Interaction between consumers and emerging forms of artificial intelligence: a discriminant analysis

also have an important role in the acceptance of robots and anthropomorphic characteristics. For instance, for the domains in which the consumer is familiar to technology (eg. online banking) robots and artificial intelligence systems are more easily accepted in comparison to other fields (eg. online legal advice).

In future research, we aim to investigate the factors that affect the acceptance, preferences, and trust towards artificial intelligence systems and robots. We aim to investigate the role of the context in the preference for a certain robot as well as the role of personalization and anthropomorphic characteristics in the development of trust in the interaction between consumers and robots.

The increased efficiency of artificial intelligence systems will determine a higher inclusion of robots in our everyday life and the services provided by several companies. This will lead to several changes in the life of the consumer. From a marketing and consumer research perspective, it is important to analyze if consumers are ready for these changes and to observe their reaction to these changes. For this reason, the research on the interaction between consumers and robots is important for business development and marketing strategies.

\section{Acknowledgments}

The authors thank the anonymous reviewers and editor for their valuable contribution.

\section{Funding}

This work was co-financed from the European Social Fund through Operational Programme Human Capital 2014-2020, project number POCU/380/6/13/125015 "Development of entrepreneurial skills for doctoral students and postdoctoral researchers in the field of economic sciences.

\section{Author contribution}

$\mathrm{CP}$ and IE conceived the study and were responsible for the design and development of the data analysis, data interpretation, and literature review.

\section{Disclosure Statement}

The authors have not any competing financial, professional, or personal interests from other parties.

\section{References}

1. Barrat, J., (2015), Why Stephen Hawking and Bill Gates Are Terrified of Artificial Intelligence, Huffington Post

2. Brynjolfsson, E., \& McAfee, A., (2014), The second machine age: Work, progress, and prosperity in a time of brilliant technologies, New York, NY: WW Norton \& Company 
Pelău, C., Ene, I., (2020)

Interaction between consumers and emerging forms of artificial intelligence: a discriminant analysis

3. Brynjolfsson, E., \& McAfee, A., (2012), Winning the race with ever-smarter machines, MIT Sloan Management Review, 53(2), 53

4. Buchanan, L., \& O'Connell, A., (2006), A brief history of decision making, Harvard Business Review, 84(1), 32

5. Goudey, A., Bonnin, G., (2016), Must smart objects look human? Study of the impact of anthropomorphism on the acceptance of companion robots, Recherche et Application en Marketing (English Edition), 31, 2-20

https://doi.org/10.1177/2051570716643961

6. Guszcza, J., Lewis, H., Evans-Greenwood, P., (2017), Cognitive collaboration: Why humans and computers think better together, Deloitte University Press

7. Lee, B., Cranage, D.A., (2018), Causal Attributions and Overall Blame of SelfService Technology (SST) Failure: Different from Service Failures by Employee and Policy, Journal of Hospitality Marketing Management, 27(1), 61-84

8. Liu, S.Q., Mattila, A.S., (2019), Apple pay: coolness and embarrassment in the service encounter, International Journal of Hospitality Management, 78, 268-275, https://doi.org/10.1016/j.ijhm.2018.09.009

9. Metzinger, T., Bentley, P., Häggström, O., Brundage, M., (2018), Should we fear artificial intelligence?, European Parliamentary Research Service, Scientific Foresight Unit (STOA), March 2018, PE 614.547

10. Pelau, C., Ene, I., (2018), Consumers' perception on human-like artificial intelligence devices, Proceedings of the 4th BASIQ International Conference on New Trends in Sustainable Business and Consumption (BASIQ), 197-203

11. PwC, Consumer Intelligence Series, (2017), Bot.Me: A revolutionary partnership, How AI is pushing man and machine closer together, https://www.pwc.com/us/en/services/consulting/library/consumer-intelligence-

series/artificial-intelligence.html (Accessed 10th of March 2020)

12. PwC, Technology Series, (2017), The Essential Eight technologies, https://www.pwc.com.au/pdf/essential-8-emerging-technologies-artificial-

intelligence.pdf (Accessed 10th of March 2020)

13. Sadler-Smith, E., \& Shefy, E., (2004), The intuitive executive: Understanding and applying 'gut feel' in decision-making, The Academy of Management Executive, 18(4), 76-91

14. Taylor, T., Dorin, A., Korb, K., (2014), Digital Genesis: Computers, Evolution, and Artificial Life, Presented at the $7^{\text {th }}$ Munich-Sydney-Tilburg Philosophy of Science Conference: Evolutionary Thinking, University of Sydney, 20-22 March 2014

15. Thrall, P.H., Bever, J.D., Burdon, J.J., (2010), Evolutionary change in agriculture: the past, present and future, Evolutionary Application 3(5-6): 405408, doi: 10.1111/j.1752-4571.2010.00155 